\title{
Implementing the Role of School Committee in Enhancing of Educational Quality (Study Case in Islamic Primary School at Mataram Nusa Tenggara Barat, Indonesia)
}

\author{
Lukman Hakim \\ \{lukmanuinmataram@gmail.com\} \\ Universitas Islam Negeri Mataram, Lombok, Indonesia
}

\begin{abstract}
The purpose of this research is to find the implementation of the role of school committee at primary school Mataram Nusa Tenggara Barat. This research is qualitative that refers to descriptive research. The data was collected through observation, interview, documentation, and questionnaire. Data analysis is qualitative through an inductive approach. To get the validity data is used Lincoln and Guba's theory is credibility, transferability, dependability and confirmability. The research finding shows that implementation the role of school committee are supporting agency, an advisory agency, controlling agency, mediator.
\end{abstract}

Keywords: Committee, Role, School, Educational, Quality

\section{Introduction}

School Committees have been formed in all education units in Indonesia. The existence of the Education Council and the School Committee has not fully been able to encourage the improvement of the quality of education services. Due to the factors that are still low in the understanding of the community and education stakeholders about the position, role and function of the Education Council and School Committee. Even though, the Education Board and School Committee have a big role in the process of successful education. Therefore, the government launched a School Committee empowerment program to improve the performance of the School Committees. This program is carried out bottom-up by the District / City Education Board so that the empowerment program develops through the needs of the School Committee on performance improvement activities. Activities that have been planned in the empowerment program include Management of School Relations with the community and ongoing guidance so that the operational activities of education in schools run effectively and efficiently. Thus, the community will provide positive responses and trust in the implementation of the education process and the educational goals set can be achieved. But the goal of education so far has not been achieved in accordance with the expectations and provisions that have been determined.

This problem is also exacerbated by inefficient, democratic, equitable and participatory education management. It happens as a result of the autonomy of education and professional management at the level of local government and education units that have not been fully 
realized. Because the management function has not been maximally used for coordination between the centre and the regions.

The application of management functions in the management of education is very much dependent on the leader and management of the school itself. A manager's success is measured based on his ability to carry out these management functions.[1] A manager or principal is essentially a planner, organizer, leader and controller. The implementation of education in school has not fully carried out the mandate of the law cited in article 8; in fact, the success of education is not only determined by the education process in school and the availability of facilities and infrastructure but also determined by the family and/or community environment. Therefore, education is a shared responsibility between government (schools), families and communities. It means that the parents and the community have the responsibility to participate. Such as Sumarsono, et.al found in their research that parents participation in improving the quality of education of elementary schools is manifested in the aspects of learning, students affair, facilities and infrastructure, public relations, educational finance, and school personnel. [2] Therefore, it is necessary to establish a school committee. But the role of the Islamic school committee at this time has not been able to improve the management of the implementation of education in schools.

Some problems related to the formation of school committees, among others, first, socialization is still top-down. Second, the lack of understanding of teachers and parents towards the committee. Third, the committee was formed by the principal. It aims to be considered to have run a government program, so that there is no pressure from the agency, the existence of the committee is mandatory in schools. However, on the other hand, there have been no initiatives from the community or teachers to form.

Based on several phenomena that occur in each research location, there appears to be a difference between the ideal conditions of the committee in supporting learning and factual conditions. It is interesting to study because the existence of the committee is very urgent in the implementation of learning in Islamic schools. The problem of the role and function of the committee for schools is not just a matter of the existence of parental representation on the implementation of education. However, how school committees can effectively become part of the implementation of education. The Islamic school committee is the link between the educational process for students. Thus, there is an effective coordination of the needs of students and parents with the school. Various policies that have been determined are in accordance with the needs of parents in the implementation of the education process. Because the school is a place to result in the next generation. So, the school committee will play an important role in the education process. Like as Nemes research focuses on the involvement of school committees in the preparation and implementation of Whole School Development Planning (WSDP), he found school committees were mostly involved in the preparation, implementation monitoring and evaluation of WSDPs.[3] as well as the research from Pradhan, et.al that improving educational quality through enhancing community participation. It is as part of the role school committee. [4] the same research from Shafa that studies about whole school improvement programme.[5]

Based on the problem above, the formulation of the problem in this research as follows: how is the role of the school committee to enhance the educational quality in Islamic primary school at Mataram? 


\section{Literature review}

\subsection{School comittee}

Every school in various countries has parents' involvement in the education process. In general, the authority of the school committee is limited to the involvement of promotion and transfer of teachers from the education office, guiding shopping grants and participating in the design and implementation of school development plans.[6] According to Beare in Newton and Tarrant that "As a consequence of a range of factors, including the bad press on state schools, the increasing influence of market forces on education and attitudes and influence of central governments, in many countries an increasing number of children are attending non-state schools, particularly church and independent schools. [7]

Establishment of the School Committee which has been stipulated in the Decree of the Minister of National Education No. 044 / U / 2002 dated April 2, 2002, the Decree of the Minister of National Education has subsequently been stated in Article 56 of Law No. 20 of 2003 concerning the National Education System as follows:

a) The community plays a role in improving the quality of education services which include planning, monitoring and evaluating education programs through education boards and school/community committees.

b) The education council as an independent institution is formed in improving the quality of education services by giving consideration, the direction of support and personnel, facilities and infrastructure, and supervision of education at the National, Provincial and Regency / City levels that do not have a hierarchical relationship.

c) School Committees, as institutions establish, are formed and play a role in improving the quality of education services by giving consideration, direction and support of personnel, facilities and infrastructure, and supervision of education at the education unit level.

The School-Based Management Working Group of the West Java Province Education Office said "The school committee is a non-political and non-profit body or institution, formed based on democratic deliberation by education stakeholders at the school level as a representation of various elements responsible for improving the quality of processes and results education. [8]

According to Townsend, at present, the management of the school committee has accepted the requirements to support the principles of primary education and set policies to improve the sustainability of education so that this is appropriate for the implementation of structures that will follow the development of school-based education. So, there are two options for opening a school. First is to establish a support committee that is ready to run the management of the school committee that will be held in the education community. Second is the expansion of school committee management and committee membership. [9] Therefore, it can be concluded that school committees are considered to have high performance if they have carried out all operational activities properly in accordance with the role they carry out, which includes all school management activities, ranging from managing students, curriculum, teaching staff and education, facilities, and infrastructure, to financing/school finance.

Based on some of the opinions above, it can be concluded that empowering school committees optimally, including in overseeing financial use, transparency in the use of education fund allocations is more accountable because of aid funds from the centre flow to schools through the supervision mechanism of school committees in which there are community representatives. Decentralization of education has implications for the provision of subsidies for school finance to ease the burden on the community in education and to provide educational services that affect the community. That way, the use of funds from both the community and 
the government can be strictly monitored according to the School Budget and Income Plan proposed by the education unit.

\subsection{The Role of School Comitte}

Contextually, the role of the school committee are (1) The advisory agency in determining and implementing education policies in education units, (2) The supporting agency, both in the form of financial, thought and energy in the implementation of education in education units, (3) Control agency in the framework of transparency and accountability in the administration and output of education in education units, and (4) Mediator between government (executive) and community in education units. [10]

The Ministry of National Education in its book Community Participation outlines the seven roles of the school committee in administering schools, namely:

1. Helping the improving the smooth running of teaching and learning activities in schools, both facilities, infrastructure and technical education

2. Conducting student attitudes and behaviour. Assist efforts to stabilize schools in realizing guidance and development of piety towards God Almighty, democracy education from an early age (national and state life, preliminary state defense education, citizenship, organization, and leadership), skills and entrepreneurship, physical fitness and exercise, power creation and creativity, and appreciation of art and culture.

3. Looking for funding sources to help disadvantaged students

4. Conducting school assessments for the development of curriculum implementation, both intra and extracurricular and the implementation of school management, head/vice principal, teachers, students and employees

5. Giving appreciation for the success of school management

6. Discussing the proposed Draft School Budget and Revenue

7. Asking schools to hold meetings for certain purposes. ${ }^{[11]}$

Thus, it can be concluded that education input is everything must be available because of the need for the continuity of the process. Input education includes human resources and software as well as expectations as guides for the ongoing process and achievement of targets. The process of education is the change of something into something else. Something that affects the ongoing process is called input, while something obtained from the process results is called output. Education output is the result of school performance. School performance is school achievement resulting from school processes/ behaviour. The role of the school committee has been elaborated and explained in the law. Law Number 20 of 2003 concerning the National Education System as a juridical basis for the administration of education. The school committee is contained in article 56 paragraph 3: The school committee, as an independent institution, is formed and plays a role in improving the quality of services by giving consideration, direction, and support for personnel, facilities and infrastructure, and education supervision at the education unit level. In accordance with article 56 paragraph 3 of 2003 concerning the Law on the National Education System, there are several functions of the school committee, namely: (1) consideration / Advice, (2) direction / meditate, (3) support (support), and (4) supervision/control.

\section{Method}

The method research is a descriptive qualitative method. Qualitative research has two main objectives, namely first, describing and revealing and secondly describing and explaining. This 
is in line with Sugiyono explanation that the qualitative method is used to obtain in-depth data which is a data contains meaning. The meaning is the actual data. Data is definitely a value behind the data that appears. [12] Therefore, in this study, researchers did not emphasize the generalization of the data obtained, but emphasized the effectiveness of school committee management in contributing to the implementation of education in Mataram.

The participant of the research is chairman, teacher, and parents. The location of research is Madrasah Ibtidaiyah Negeri (MIN) Karang Baru, Madrasah Ibtidaiyah (MI) Ittihadul Islamiyah Ampenan, dan Sekolah Dasar Integrasi Terpadu (SDIT) Sekarbela. The process of collecting data for this research consists of several types;

1. Observation. It is made to obtain a real event to answer research questions.

2. Documentation. In this study, researchers will track written information related to teacher performance such as certificates, learning tools, results of student assessments conducted by the teacher, physical evidence of curriculum development and other data that have relevance to research.

3. Interview. It conducted by researchers in three locations by determining who will be interviewed, namely, committee elements, school residents and stakeholders that are related to the managerial activities of the committee.

4. Questionnaire.

In this study, qualitative data analysis is used with an inductive approach in drawing conclusions from existing data. This means that researchers depart from facts, information and empirical data to build theory or depart from cases that are specifically based on real experience (speech, the behaviour of research subjects or research field situations), to be formulated into models, concepts, theories, principles, or definitions are general. There are three activities to check the validity of the data in this study, including credibility, dependability and reliability.

\section{$4 \quad$ Finding}

This study has conducted questionnaires in three research locations. each school consists of 10 participants consisting of a headmaster, 3 teachers and 6 parents. The results of questionnaire distribution have been made in percentage form. Each percentage that is presented is the answer needed to maximize the role of the school committee in improving the quality of education. The following is the graph of percentage the role school committee; 


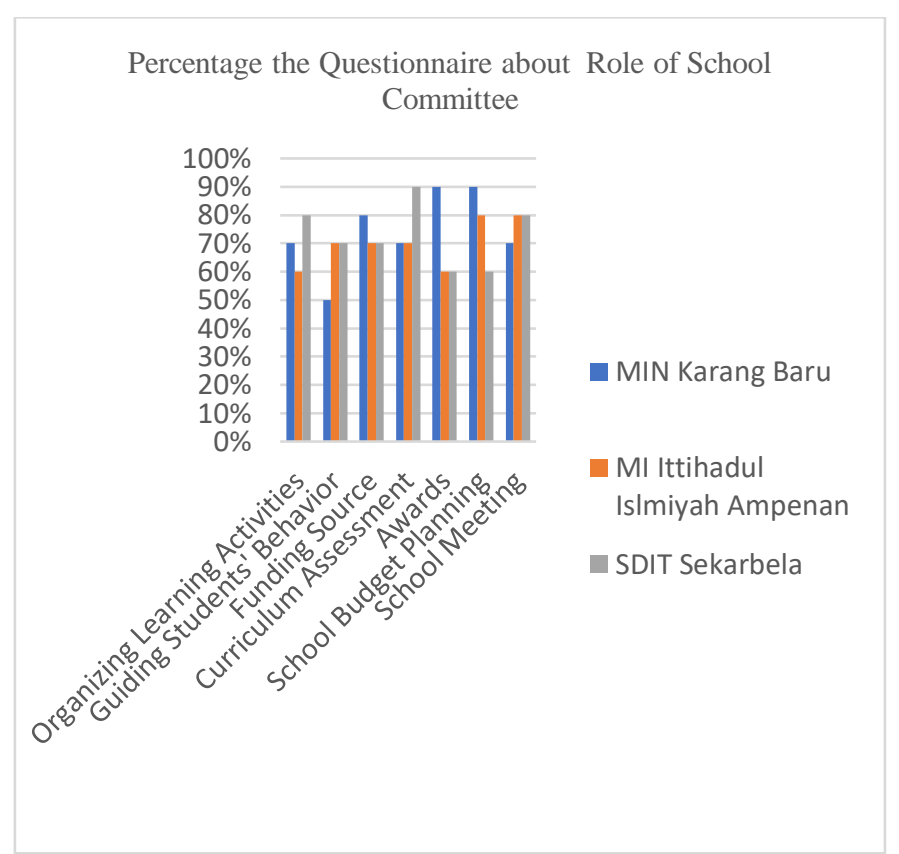

Figure 1. Percentage of the Role School Committee

The graph above shows the result of analyzing 7 components of questions to know the role of the school committee. Each component consists of 5 questions. The results of data processing from the graph above show that the role of school committees is very much needed and influences the implementation of educational programs in primary schools. This can be seen from the percentage level above 50\%. The first component has the average percentage of $70 \%$. It means that organizing the process of learning needs a school committee's input. The second component gets the average of the percentage of $63.3 \%$. It means that school committees have the responsibility to provide input on handling student behaviour. The third component gets the average percentage of $73.3 \%$. It means that school committees have the responsibility to find the funding. The fourth component gets the average percentage of $76.7 \%$. It means that the school committees have the responsibility to give the input relates to the needs' curriculum. The fifth component gets the average percentage of $70 \%$. It means that school committees have the responsibility to control the process of awards giving in the school. The sixth component gets the average percentage of $76.7 \%$. It means that school committees have the responsibility to control and giving the advice about the financial problem in the school. The seventh component gets the average percentage of $76.7 \%$. It means that school committees have the responsibility of attendance in school meeting as annually.

\section{Discussion}

The Committee is an important part of the implementation of learning and education in education units. The implementation of learning is intended to be a whole series of education ranging from planning, implementing, and evaluating as well as outputs from educational 
institutions. With the fulfilment of all components of education including committees as part of education stakeholders, it is expected that quality education is not only an aspiration or a vision that cannot be realized but with the involvement and participation of these components is the basis for achieving good quality and output and has the advantage of being reflection of the importance of our education.

The implementation of the roles of the school committee at MIN Karang Baru that the existence of the school committee has been carried out properly, it cannot be said to be optimal or perfect. The realization of role school committee at MIN Karang Baru in managing of learning activity relates with the figure of the chairman of school committee. During this time at MIN Karang Baru, the existence of the committee with its expertise or figures such as when the committee came from academics influenced the interest in this school. As expressed by the headmaster: "If the committee comes from academics, parents are very interested in sending their children to MIN Karang Baru, even though the committee chairman does not blend in with the community, the important thing that he is an academic."[13]. For them, someone who has a higher education level will have a good influence on the implementation of the education process at MN Karang Baru. This reason is logical for the community. Especially in rural Indonesia, people who have high academic levels are still rare. They still consider academic people to be people who have a lot of good and can have a positive influence on the changes in their lives.

School committee participation in the learning and teaching process is also very large. Together with the school, they evaluate and improve the learning and teaching process needs. In addition, some activities carried out by school committees are not only oriented towards education level. Various activities are held for the benefit of all teachers, children, parents so that they have a close level of unity. For example, the implementation of ESQ training, the practice of buying and selling for students, compensation activities, solidarity action for Palestinians, and student day. The level of public trust in Karang Baru MN is derived from the activeness of school committees in the implementation of education. Committee participation as if in various events shows a high level of social concern for school needs. So that this creates a different view of society towards MN Karang Baru.

School Committees in Al-Ittihadul Islamiyah MIS Ampenan with achievements and support for the provision of education that is so high should be positively appreciated. Activities carried out related to the implementation of education and supporting facilities. Educational activities include committees carrying out all their roles and functions even though they are not yet maximal. The role of the committee as a consideration, support, control, and as a mediator has been successfully demonstrated. The consideration which is one of the roles of the committee is carried out in determining policies and their implementation. Supporters were also carried out very well, support in the implementation of education and facilities support was evident from their work in adding classrooms located on the second floor of the Al-Ittihadul Islamiyah Ampenan MIS building. Likewise, the role of intensive control is carried out.

In addition to the meeting, control is carried out with a visit to the school. Visits to schools are intended to see the learning process, discipline, especially discipline when entering school. Other roles that are also carried out by the committee are as mediators between schoolgovernment, and school-community mediators. For example, when a school needs assistance both financially and education personnel related to government policy, the committee also takes part in establishing good communication and coordination with the government through the Ministry of Religion, Mataram, as well as mediators between schools and the community. The Committee lobbies mobilize the community to play an active role in the delivery of education, both financial, labour, and advice to school. 
Extra activities which are a form of cooperation between committees and school include the implementation of Scouting exercises every afternoon on Saturday, the study of Al-Quran (Tahfiz and Tilawah) every Friday, always be the routine of students. Likewise, kasidah exercises, speeches, and so on. These activities are of value to these school, so they can compete with other public schools in the region, one example of applying discipline is half an hour the teacher before entering school hours, the teacher is already in school. This discipline is often the main attraction of this school. Discipline is always maintained every day. So that schools are still in demand by parents, even though there are also public schools in this area. However, the discipline applied became a special added value for the Al-Ittihadul Islamiyah MIS Ampenan.

Based on the explanation above, it can be concluded that the school committee in the AlIttihadul Islamiyah MIS is active. School committees strive to always be aware of the development of educational activities ranging from the implementation of the education process, policy making, financial management, frequent meetings, receiving and requesting financial reports and all activities in the education process, building collaboration, being a mediator for school relations with the community, always giving input and recommendations on all policies taken by the school, and so on.

The various roles that have been carried out by the school committee in Ampenan's AlIttihadul Islamiyah MIS show that the school committee has carried out the mandate of the legislation relating to the role of the school committee. So, the implementation of education is carried out based on applicable regulations and community needs. The role of parents represented on the school committee is a concrete manifestation of the application of schoolbased management. When the lower community participates in the implementation of education, the lower the quality of education. Realization in school-based management in the implementation of education has broad authority in managing school resources to be more optimal. Therefore, school management has a big role in the development of education.

The role of the school committee in SDIT Anak Sholeh is very optimal in the learning process. The school committee which has representatives in each class in the form of a class forum where the class forum has the task of seeing and participating directly in learning every day. The inhibiting factors of learning are the tasks and responsibilities of class forums such as the availability of markers, erasers, drinking water. Likewise, the other needs that can support learning every day are always a concern of this class forum.

The role of the school committee in supporting financial problems is clearly visible. Because in each class there is a coordinator to raise funds when there are activities. This contribution is also used for activities in the forum. So, the school committee's control in terms of financial needs and uses is clearly realized. They routinely supervise and control financial transparency. In addition, school committee support appears in various initiatives or various activities to support the smooth and progress of the learning and teaching process. The activeness of the committee is also seen in building cooperation with outside parties such as communities and companies. This collaboration was built to support school needs in the implementation of education.

\section{Conclusion}

Implementation of the role of the school committee in MIN Karang Baru, Al-Ittihadul Islamiyah MIS and SDAR Sekarbela Mataram, namely: (1) Advisory agency in determining 
and implementing education policies in education units, (2) Supporting agencies, both tangible financial, thought and energy in carrying out education in education units. (3) the controlling agency in the framework of transparency and accountability in the delivery and output of education in education units. (4) Mediators between the government (executive) and the community in the education unit. While the implementation of the committee function in MIN Karang Baru, Al-Ittihadul Islamiyah MIS and Sekarbela Mataram SDIT are: (1) Encourage the growth of community attention and commitment to quality education, (2) Collaborating with the community (individuals / organizations / businesses / the industrial world) and the government with regard to the implementation of quality education, (3) Accommodating and analyzing the aspirations, ideas, demands and various educational needs raised by the community. (4) Provide input, consideration, and recommendations to education units regarding: (a) Education policies and programs, (b) School education and expenditure budget plans (RAPBS / RKAS), (c) Educational unit performance criteria, (d) Criteria education staff, (e) Criteria for education facilities, and (f) Other matters related to education. (5) Encouraging parents and communities to participate in education to support quality improvement and education equity, (6) Raising public funds in the framework of financing education in educational units, (7) Evaluating and supervising education policies, programs, implementation and output in education units.

\section{References}

[1] Wahjosumijo. Oakhill, Kepemimpinan Kepala Sekolah, Tinjauan Teoritik dan Permasalahannya. Cet.III. Jakarta: Raja Grafindo, 2002, p.96.

[2] Sumarsono, Raden Bambang, Parents' participation in Improving the Quality of Elementary School in the City of Malang, East Java, Indonesia, International Education Studies; Vol. 9, No. 10; 2016, pp.256-262

[3] Nemes, Joyce, School Committees in the Context of Preparing and Implementing Whole School Development Planning, Journal of Education and Practice Vol.4, No.7, 2013, pp.73-79

[4] Pradhan, Menno, et.al, Improving Educational Quality through Enhancing Community Participation: Result from a Randomized Field Experiment in Indonesia, America Economic Journal: Applied Economics Vol.6 No.2, 2014, pp.105-26

[5] Shafa, Mola Dad, Initiating Reform through Whole School Improvement Programme: Aga Khan University's Experiences from Pakistan. Journal of Education \& Human Development Vol.3 No.1, 2014, pp.347-368

[6] Felipe Barrera-Osorio, et.al. Decentralized Decision-Making in Schools The Theory and Evidence on School-Based Management. Washington DC: The World Bank. 2009.p.8

[7] Newton, Colin and Tony Tarrant. Managing change in schools a practical handbook. London and New York. Routledge. 2002

[8] Depdiknas. Manajemen Mutu Berbasais Sekolah. Jakarta: Dirjen Dikdasmen, 2004, p.63.

[9] Tony Townsend. Effective schooling for the community core plus education. London \& New York: Routledge. 2003, p.147

[10] Kep Mendiknas Nomor: 044/U/2002 Tanggal 2 April 2002, p.31

[11] Depdiknas, Manajemen Peningkatan Mutu Pendidikan Berbasis Sekolah, Jakarta: Depdiknas, 2001, p. 17

[12] Sugiyono, Memahami Penelitian Kualitatif, Bandung: CV. Alfabeta, 2005, p.3

[13] Wawancara Dengan Kepala Sekolah MIN Karang Baru Drs M. Irwan Ali Wardaini, S.Pd, M.Pd pada Tanggal 5 Februari 2015 